\title{
Settlement of brachyuran megalopae in Delaware Bay: an analysis of time series data
}

\author{
M. B. Jones, C. E. Epifanio* \\ College of Marine Studies, Hugh R. Sharp Campus, University of Delaware, Lewes, Delaware 19958, USA
}

\begin{abstract}
Crab megalopae were collected daily in a secondary estuary near the mouth of Delaware Bay during 4 annual settlement seasons (1989 to 1992). The sampling site consisted of a raft from which 4 replicate collectors were deployed vertically at the water column surface. Each replicate collector was constructed from a segment of $20 \mathrm{~cm}$ diameter PVC pipe. The pipe was covered with a removable sheath of loosely interwoven strands of polypropylene upon which the megalopae settled. We assumed that settlement on the collectors was proportional to settlement on natural substrata near the sampling site each day. The 3 families Ocypodidae (Uca spp.), Portunidae (Callinectes sapidus), and Xanthidae comprised the vast majority of the megalopae collected. Daily settlement events occurred in clusters. Auto-correlation analysis showed decorrelation times ranging from 2 to $3 \mathrm{~d}$ for C. sapidus and from 1 to $2 \mathrm{~d}$ for xanthids and $U_{C a} \mathrm{spp}$. These define the durations of typical settlement episodes for each taxon. Xanthids and Uca spp. began to settle in mid summer and continued into early autumn. Major settlement of C. sapidus never occurred until late August, and the intensity of settlement usually decreased by late October. Results of $G$-tests showed no effect of lunar phase on settlement events, regardless of year or taxon. Likewise, binomial goodness-of-fit tests showed no significant effect of the spring/neap cycle on settlement. However, the observed frequency of settlement events for $C$. sapidus was significantly greater than expected for southward wind events in all $4 \mathrm{yr}$, while there was no consistent association between winds and settlement of Uca spp. or xanthids. Of the 3 taxa studied, only C. sapidus relies on wind-driven processes for transport to settlement sites. Transport of $C$ sapidus megalopae back into the estuary requires the coincident occurrence of a southward, alongshore wind event and a nearby patch of megalopae. The stochastic nature of this co-occurrence explains the observed temporal variations in settlement of $C$. sapidus in the estuary.
\end{abstract}

KEY WORDS: Recruitment - Larval transport - Wind-driven $\cdot$ Megalopae $\cdot$ Crabs

\section{INTRODUCTION}

Larvae of some species of estuarine crab are retained within the estuary until settlement, while others are flushed to the continental shelf where they may develop through a number of zoea stages before returning to the estuary as megalopae. For example, most species of mud crab (f: Xanthidae) produce zoea larvae that are retained in the estuary, while the fiddler crabs (Uca spp.) and blue crabs (Callinectes spp.) have zoea larvae that are exported to the continental shelf (Epifanio et al. 1988). Callinectes sapidus is the most common species of blue crab in the Middle

•E-mail: epi@brahms.udel.edu
Atlantic Bight (MAB). Capable of swimming, $C$. sapidus females migrate to the mouth of the estuary in late spring and summer to spawn. Hatching occurs near high slack water, and zoea larvae are transported seaward on the ensuing ebb tide (Provenzano et al. 1983). Development through 7 zoea stages takes place in the open waters of the continental shelf and requires approximately $4 \mathrm{wk}$. Zoea larvae remain in surface waters throughout development, and retention in the MAB is controlled by a wind-driven, northward-flowing current located between 20 and $60 \mathrm{~km}$ off the coast (Epifanio et al. 1989). This northward current occurs seasonally and is located between a strong, southward coastal current that hugs the immediate shoreline and a more diffuse southward flow along the outer continental shelf. Re-invasion of the estuaries of the MAB 
occurs during the megalopa stage (Epifanio et al. 1984, Johnson 1985), and available evidence suggests that transport into the estuaries may be effected by southward wind events that occur in early fall (Goodrich et al. 1989, Little \& Epifanio 1991). Southward wind events in the MAB blow parallel to the coastline, and the resulting Ekman flow results in strong, depth-averaged movement of water toward the shore. This produces an accumulation of water along the coast and causes an increase in subtidal sea level at the mouth of an estuary. This process is called 'downwelling', and the increase in subtidal sea level is called 'coastal setup' or 'positive anomaly'

There is extensive subtidal flow into an estuary during periods of coastal set-up, and this provides an obvious mechanism for the transport of Callinectes sapidus megalopae from the shelf to the estuary (Wong \& Garvine 1984). However, some studies show springtide peaks in settlement of C. sapidus, which indicates that megalopae may also take advantage of greater tidal flux associated with full or new moons to reinvade the estuary (van Montfrans et al. 1990). In either case, retention of megalopae once they enter the estuary appears to have a behavioral component, i.e. the megalopae undergo vertical migration to move up the estuary during periods of flooding tides (Epifanio et al. 1984, Brookins \& Epifanio 1985, Dittel et al. 1991).

Adult fiddler crabs are semiterrestrial and their movements are restricted because of their inability to swim. Nevertheless, fiddler crab larvae are flushed to the continental shelf from tidal creeks during maximum ebb flow (Christy 1982). Early stages of larvae remain planktonic, while later larval stages and megalopae assume deeper positions in the water column to take advantage of subtidal landward flow (Epifanio et al. 1988). Re-invasion of the estuary is undertaken by the megalopae (Little \& Epifanio 1991).

Adult xanthid crabs are also incapable of swimming and, therefore, have restricted home and spawning ranges. Xanthid larvae may have an endogenous rhythm of vertical migration wherein zoeae swim upward in the water column during flood tides and passively sink to deeper depths during slack tide and ebb tide phases (Cronin \& Forward 1979, Cronin 1982). However, related work indicates that exogenous cues such as hydrostatic pressure and gravity may also be important in this type of vertical migration (e.g Wheeler \& Epifanio 1978, Sulkin et al. 1983). Specifically, xanthid larvae are negatively geotactic and show high barokinesis. Thus, they may move higher in the water column on flood tides, resulting in net upstream transport.

Clearly there is a large amount of information concerning the dispersal of crab larvae in the MAB. However, much of this data has been collected in studies wherein the sampling scales were not well matched to the relevant physical and biological processes. For example, Epifanio et al. (1989) made weekly measurement of crab larval abundance off Delaware Bay and tried to infer patterns of transport from available current-meter records. Subsequent analysis showed that weekly sampling was inadequate because larval patches were often transported completely out of the sampling area in less than 1 wk. Other studies (e.g. McConnaugha et al. 1983, McConnaugha 1988) have attempted to reconstruct larval trajectories from data collected at even lower frequencies, again resulting in a mismatch between physical and biological processes. From a physical perspective, the estuary and adjacent continental shelf are very dynamic areas, and any real understanding of larval transport at the estuary-shelf interface requires high-frequency sampling. Recent studies have provided hourly time series of larval density for as much as 12 consecutive tidal cycles (e.g. Little \& Epifanio 1991, Dittel et al. 1991, Rowe \& Epifanio 1994). However, this type of study is very expensive in both labor and ship time. In this paper, we present the results of a recruitment study that employed highfrequency (daily) sampling in the mouth of Delaware Bay, USA. The study used passive collectors that minimized both labor and ship costs. The investigation involved 3 major taxa and was part of a coast-wide investigation that was initiated at several sites extending from Long Island Sound to Texas. Settlement events were analyzed in relation to available data for lunar phase, alongshore wind velocity, and subtidal sea level.

\section{MATERIALS AND METHODS}

Megalopae collection and analysis. Megalopae were collected daily in the mouth of the Broadkill River during 4 annual settlement seasons. The Broadkill River is a secondary estuary located $6 \mathrm{~km}$ from Cape Henlopen at the mouth of Delaware Bay, USA (Fig. 1), and the sampling site consisted of a raft from which collectors were deployed vertically at the water column surface. Each replicate collector was constructed from a $38 \mathrm{~cm}$ segment of $20 \mathrm{~cm}$ diameter PVC pipe. The pipe was covered with a removable sheath of air-conditioning filter material; this material consisted of a mat of loosely interwoven strands of polypropylene. Previous studies (e.g. Goodrich et al. 1989) have shown that crab megalopae readily settle on this type of collector.

The collectors were deployed so that the tops of each unit floated 1 to $2 \mathrm{~cm}$ above the water column surface in calm water (preliminary studies showed no difference in settlement on collectors at the surface or deeper in the water column; low-tide depth at sampling site $=3 \mathrm{~m}$ ). After a collector had been in the water 


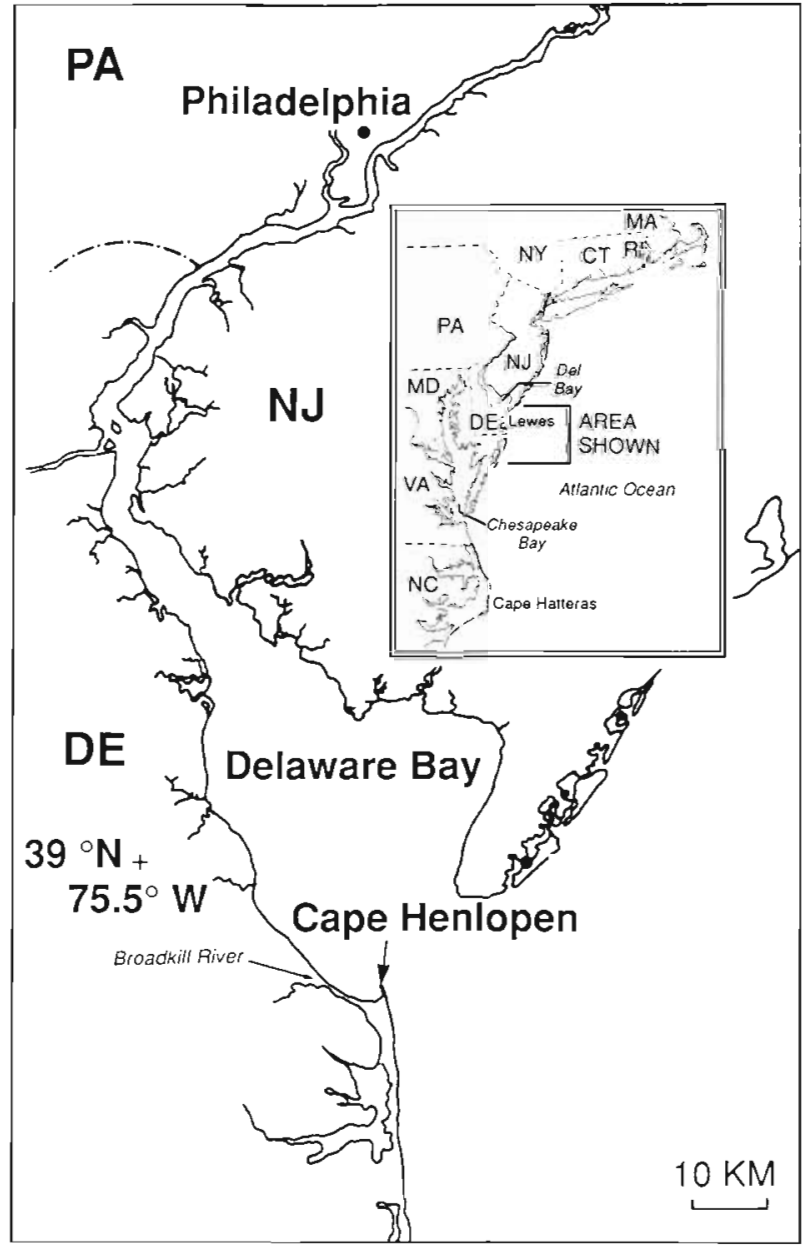

Fig. 1. Sampling site and surrounding area, USA

for $24 \mathrm{~h}$, it was replaced with a clean collector, and megalopae were removed with serial rinses from a fresh-water hose. Megalopae were concentrated on a $0.5 \mathrm{~mm}$ sieve and stained with Rose Bengal to facilitate removal from the sample. Megalopae were identified from various keys and original descriptions (Dittel \& Epifanio 1982). Callinectes megalopae were identified to species, but it was impossible to identify $U_{C a}$ beyond genus because the megalopae of this genus have identical morphological features. Abundant spawning populations of both $U$. minax and $U$. pugnax occur near the sampling site. While there is sufficient morphological difference among xanthid megalopae to allow classification to species, the identification process is tedious. Because of the large number of xanthid megalopae collected in the investigation, we did not attempt to identify xanthid larvae beyond family. Abundant species near the sampling site include Panopeus herbstii, Rhithropanopeus harrisi, Neopanope sayi, and Eurypanopeus depressus.
We deployed 4 replicate collectors daily, and data were analyzed as the mean number of individuals of each species per collector per day. We assumed that this value was proportional to the number of megalopae settling on natural substrata near the sampling site each day (Metcalf \& Lipcius 1992). To allow easy graphical comparison among years, daily settlement was presented as a proportion of the maximum daily settlement, i.e. data from each year were normalized as percentages of the maximum settlement in all 4 years.

The duration of the collection period differed in each year. This reflected changing priorities over the course of the study. In 1989 and 1990, we were primarily interested in the settlement of Callinectes sapidus. Because this species is a late-season spawner (Dittel \& Epifanio 1982), we initiated sampling in mid August and continued until approximately November 1 . The time series in 1989 and 1990 were 90 and 93 d, respectively, and data were analyzed only for C. sapidus. In 1991 and 1992, we included the entire settling seasons for both xanthids and $U_{C a}$ spp. The 1991 season began in July and continued through October (150 d); the 1992 season began in mid May and again continued through October (170 d). Data from 1991 and 1992 were analyzed for all 3 taxa.

Physical analyses. Lunar periodicity: Lunar data were obtained from the U.S. Naval Observatory's Interactive Computer Ephemeris (ICE) program. Lunar quarters were specified as new moon (Lunar Days 1 to 7), waxing half moon (Lunar Days 8 to 14), full moon (Lunar Days 15 to 22), and waning half moon (Lunar Days 23 to 30 ). The data were treated as a chi-squared distribution using the $G$-test to determine any significant differences between observed and expected settlement in each lunar phase (Zar 1984). The G-test was run on synodic months, which are defined by the average number of days between recurring phases of the moon (i.e. new moon to new moon 29.5 d). Therefore, the proportions used to calculate the expected frequencies were 0.24 for the new and waxing moon periods and 0.26 for the full and waning moons.

Tides: Daily tide data for the 4 yr were obtained from NOAA tide tables. For each day in the series, 'an average daily tidal range' was calculated by using the difference between the 2 averaged high tides and the 2 averaged lows for that day. For each year we calculated the mean value for the average daily tidal ranges and then calculated the difference between this mean value and each daily tidal range. Any values greater than the mean tidal range were considered spring tides.

Wind: Hourly wind data were obtained from the U.S. Weather Service Station in Atlantic City, NJ, for each year. Because we hypothesized that alongshore winds were a likely mechanism for the transport of megalopae 
into the estuary (see 'Introduction'), we calculated the alongshore component of each hourly wind velocity:

$$
A=(S) \cos \left(\theta-190^{\circ}\right)
$$

where $A$ was the alongshore component, $S$ was the wind speed, and $\theta$ was the direction in degrees from which the wind blew. The coastline adjacent to Delaware Bay runs approximately $190^{\circ} / 10^{\circ}$ true north Thus, the alongshore component wind was set at that direction. The algorithm transformed the entire wind field into northward and southward blowing wind components. We used a $36 \mathrm{~h}$, Lanczos, low-pass filter with 6 h decimation to eliminate high frequency data (i.e. wind gusts), leaving only the low frequency wind field (i.e. prolonged winds). The Lanczos filter uses weighted, running averages with any preset hourly interval, e.g. $36 \mathrm{~h}$ in the present study. This filter generated a series of alongshore winds that were plotted as velocities every $6 \mathrm{~h}$. For binomial goodness-of-fit tests (see below), we used the daily means of the filtered wind velocities.

Sea level: For each year, we obtained hourly sea level data from a NOAA tide gauge located near the mouth of Delaware Bay, approximately $6 \mathrm{~km}$ from the study site. We passed the data through a Lanczos filter to eliminate oscillations at tidal frequencies. This provided a time series of subtidal sea level (SSL). For each annual time series, we calculated the mean value for SSL by dividing the sum of all SSL in the series by the total number of hours in the series. We then subtracted the mean SSL from each hourly SSL to generate a series of 'SSL anomalies' The time series of SSL anomalies was plotted every $6 \mathrm{~h}$, and daily means were used in binomial goodness-of-fit tests. Anomalies greater than $0.05 \mathrm{~m}$ were termed 'positive anomalies' and were assumed to be the consequence of coastal set-up.

We analyzed the association between the magnitude of megalopal settlement and concurrent physical events (i.e. alongshore winds or positive anomalies) using 2 different methods. The first consisted of cross correlation analysis (Rowe \& Epifanio 1994), and the second consisted of a goodness-of-fit test using the binomial distribution (Little \& Epifanio 1991). in the cross correlations, data were lagged in both directions with time-steps of $1 \mathrm{~d}$. In the goodness-of-fit tests, we restricted the wind analysis to southward events because winds blowing to other quadrants do not generate coastal set-up. Likewise, we restricted the analysis of SSL to positive anomalies. In both cases, expected frequencies were based on the actual frequencies of southward wind events or positive anomalies in our data sets. Separate analyses were conducted for each year. In the goodness-of-fit tests, we used a $2 \mathrm{~d}$ window in analyzing settlement events with respect to winds and SSL. For example, settlement that occurred on the day of a southward wind or $1 \mathrm{~d}$ after a southward wind was considered coincident with that wind event. This was based on the time ( $\mathrm{ca} 12 \mathrm{~h}$ ) required for the occurrence of coastal set-up after the initiation of a southward wind event (Noble \& Butman 1979). Inference level for all statistical analyses was set at 0.05 .

'Settlement events' for each taxon were defined as any daily settlement greater than $10 \%$ of the largest daily settlement for that taxon throughout the $4 \mathrm{yr}$ study. For Callinectes sapidus the largest daily settlement (97.2 megalopae per collector) occurred in 1989; thus, events for $C$. sapidus were defined as any mean daily settlement greater than 9.7 megalopae per collector. Settlement events for Uca spp. and xanthids were defined in a similar manner $1>12.4$ megalopae per collector for Uca spp. and $>12.8$ megalopae per collector for xanthids). 'Settlement episodes' were defined as a group of settlement events that were clustered in time. Settlement episodes usually began with a day of low settlement (i.e. numbers between 0 and $10 \%$ of the maximum) followed by a few days of high numbers of megalopae (i.e. numbers greater than $10 \%$ of the maximum). Defining an event as less than $10 \%$ of the maximum would have resulted in numerous peaks, many of which were single days that were uncharacteristic of the high settlement episodes. As a further check on the nature of settlement episodes, we conducted autocorrelation analysis of the respective settlement time series for each taxon. This allowed an estimate of the temporal scale of decorrelation, thus defining the temporal scale of a settlement episode.

\section{RESULTS}

\section{Temporal aspects of settlement}

Daily settlement events occurred in clusters. Autocorrelation analysis of annual settlement records showed decorrelation times ranging from 2 to $3 \mathrm{~d}$ for Callinectes sapidus. Decorrelation ranged from 1 to $2 \mathrm{~d}$ for xantinids and Ucaspp. These define the durations of typical settlement episodes for each taxon.

Temperature at the collection site showed an expected seasonality with levels rising to $28^{\circ} \mathrm{C}$ in mid summer and falling to $8^{\circ} \mathrm{C}$ by late October. Salinity varied with tidal stage; it occasionally exceeded 30 psu on flood tides and sometimes fell below 10 psu on ebb tides after heavy rains.

There were clear differences in the seasonality of settlement (Fig. 2). During each year, xanthids and Uca spp. began to settle in mid summer and continued into early autumn. In some years Callinectes sapidus megalopae appeared in small numbers in July, but major 

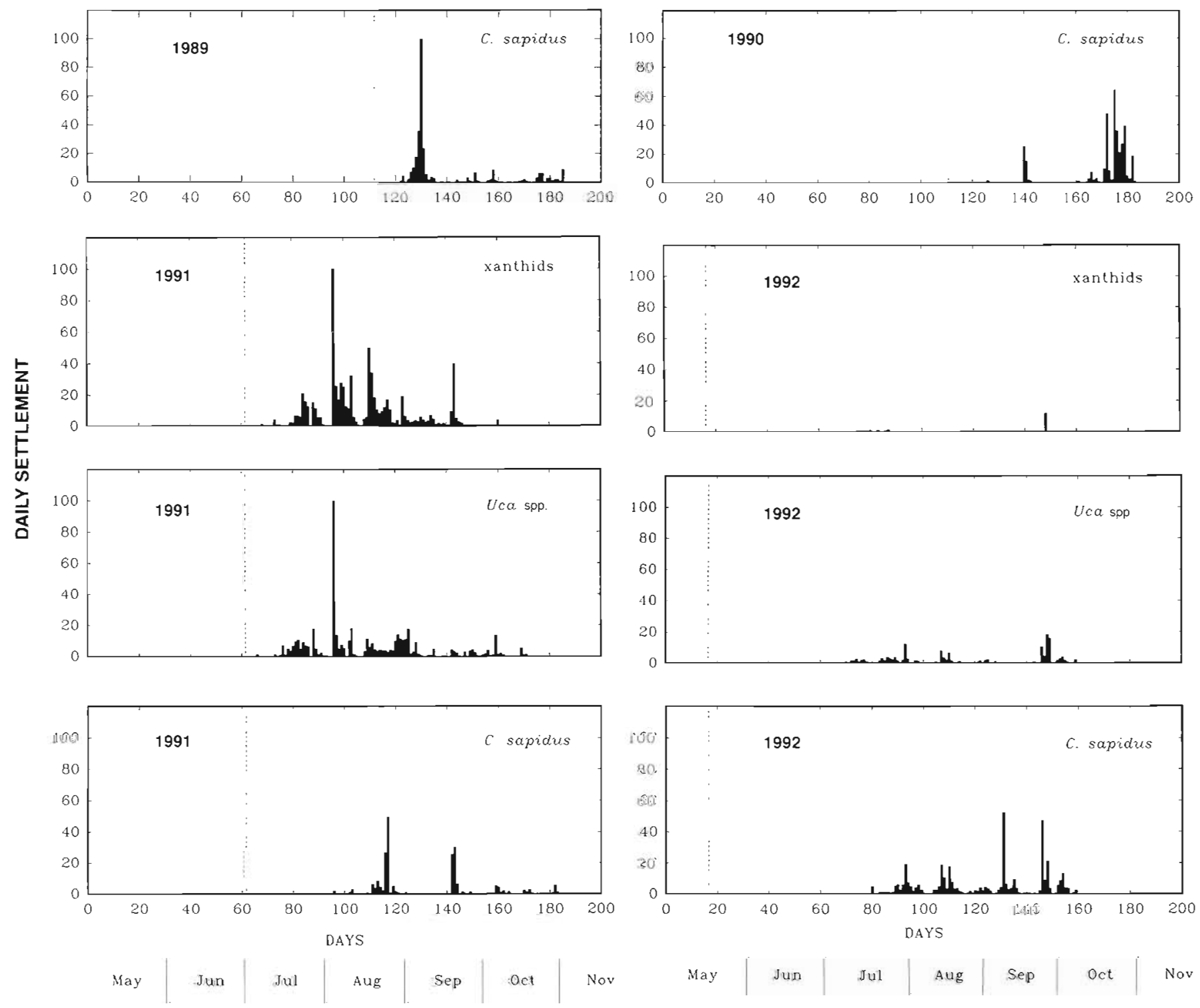

Fig. 2. Callinectes sapidus, Uca spp. and Xanthidae. Daily settlement of megalopae, 1989 to 1992 . Values are percentages of maximum daily settlement for each taxon. Physical and chemical data were collected for the entire time series. Dotted vertical lines indicate the date on which biological sampling began in each year

settlement never occurred before mid August, and the intensity of settlement usually decreased by late October. This agrees with the results of earlier work in Delaware Bay (Dittel \& Epifanio 1982, Epifanio et al. 1984). In spite of the different lengths of the annual time series, we were able to sample the important parts of the settlement season for $C$. sapidus for each of the 4 years. The total number collected was maximum in 1992 ( $n=1580$ ) and minimum in 1991 ( $n=904$ ) (Fig. 3). In 1989 and again in 1992, the vast majority of $C$. sapidus were collected in settlement episodes in early and mid September, respectively. In 1991 settlement began in mid July and continued at a low level through August. However, the bulk of annual settlement occurred in a large event in late August followed by another in mid September. In 1990 settlement had already begun when sampling was initiated in mid August; however the first episode did not occur until late September, and this was followed by several episodes in mid to late October.

Maximum abundance of Uca spp. occurred in 1991 ( $n=2488$ ). In 1991 there were low abundances of $U_{C a}$ spp. from the outset of the sampling period (mid July) with the bulk being collected in 1 settlement episode in 


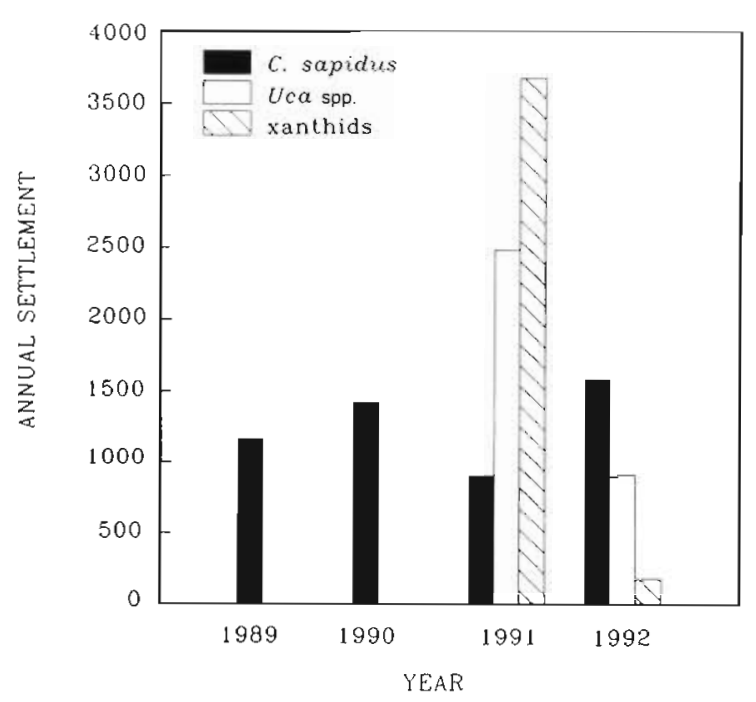

Fig. 3. Callinectes sapidus, UCa spp. and Xanthidae. Total number of megalopae collected during each year of the study

early August (Fig. 2). Settlement proceeded at low abundances until late October. In 1992, the majority of $U_{c a}$ spp. settled during 3 separate episodes, 1 in early August, 1 in late August, and 1 in late September. Settlement ceased by mid October.

Greatest settlement in xanthids occurred in 1991 ( $\mathrm{n}=$ 3674 ). For that year, 3 episodes made up the majority of xanthid collection, 2 in August and 1 in late September (Fig. 2). In 1992, there were low abundances of xanthids beginning in late June, and there was 1 major settlement event in late September.

\section{Lunar and tidal periodicity}

Results of $G$-tests showed no significant difference between observed and expected frequencies of settlement events in the 4 lunar phases, regardless of year or taxon (Table 1). This indicates that there was no effect of lunar phase on settlement.

Binomial goodness-of-fit tests showed no significant difference between observed and expected frequencies of settlement events during spring tides for Callinectes sapidus or xanthids (Table 2). However, there was a significant difference for Uca spp. in 1992.

\section{Winds and sea level}

The complete time series of filtered and decimated alongshore winds for each year shows the predictable oscillation of northward and southward blowing
Table 1. Callinectes sapidus, Uca spp. and Xanthidae. Number of settlement events during each lunar phase (see 'Materials and methods'). Results of $G$-tests showed no difference between observed and expected frequencies

\begin{tabular}{|ccccc|}
\hline & New & Waxing & Full & Waning \\
\hline Callinectes sapidus & & & & \\
1989 & 3 & 2 & 0 & 0 \\
1990 & 4 & 3 & 0 & 2 \\
1991 & 0 & 2 & 2 & 0 \\
1992 & 3 & 2 & 3 & 0 \\
Uca spp. & & & & \\
1991 & 2 & 3 & 5 & 4 \\
1992 & 3 & 1 & 0 & 0 \\
Xanthidae & & & & \\
1991 & 1 & 9 & 5 & 7 \\
1992 & 1 & 0 & 0 & 0 \\
\hline
\end{tabular}

Table 2. Callinectes sapidus, Uca spp. and Xanthidae. Total number of settlement events and number of events associated with southward winds, positive sea level anomalies, or spring tides. Significant difference between observed and expected frequencies

\begin{tabular}{|ccccc|}
\hline & $\begin{array}{r}\text { No. of } \\
\text { peaks }\end{array}$ & $\begin{array}{c}\text { Southward } \\
\text { winds }\end{array}$ & $\begin{array}{c}\text { Sea level } \\
>0.05 \mathrm{~m}\end{array}$ & $\begin{array}{c}\text { Spring } \\
\text { tides }\end{array}$ \\
\hline $\begin{array}{c}\text { Callinectes sapidus } \\
1989\end{array}$ & 5 & $\cdot 5$ & $\cdot 5$ & 0 \\
1990 & 9 & $\cdot 8$ & $\cdot 7$ & 3 \\
1991 & 4 & $\cdot 4$ & 2 & 2 \\
1992 & 8 & $\cdot 8$ & $\cdot 5$ & 4 \\
Uca spp & & & & \\
1991 & 14 & 9 & 4 & 8 \\
1992 & 4 & 3 & 1 & $\cdot 3$ \\
Xanthidae & & & & \\
1991 & 22 & $\cdot 15$ & 6 & 7 \\
1992 & 1 & 1 & 1 & 1 \\
& & & & \\
\hline
\end{tabular}

winds associated with the passage of cold fronts over the study site (Fig. 4). The data show relatively light winds during the summer months and relatively strong southward winds associated with the propagation of low pressure systems during autumn. The onset of a southward wind event usually resulted in an increase in coastal sea level; there was usually a decrease in sea level associated with northward events (Fig. 5).

Cross-correlations between alongshore wind velocity and the magnitude of megalopa settlement yielded equivocal results. For Callinectes sapidus, the correlation between southward velocity and megalopa settlement was always greatest at zero-lag or when wind was lagged backward in time by $1 \mathrm{~d}$. However, the correlation was significant only in 1989. Correlations done for the other 2 taxa were even less straightforward. 
The utility of cross-correlation analysis may have been limited by the large number of days when there was zero settlement, i.e. each day in the time series was used in the cross correlations, regardless of whether there was any settlement. This added greatly to the scatter of the data and accordingly reduced the calculated r-values.

Goodness-of-fit tests were not affected by zeros in the data set and yielded more clear-cut results. The observed frequency of settlement events for Callinectes sapidus was significantly greater than expected for southward wind events in all 4 years. The number of settlement events occurring at times of positive anomalies in SSL was greater than expected during 1989, 1990, and 1992 (Table 2). There was no significant difference between observed and expected frequencies of settlement events for positive anomalies in 1991. This may have been due to the low number of settlement events in 1991.

There was no significant difference between observed and expected frequencies of $U_{C a}$ spp. settlement during southward winds or during positive anomalies in 1991 and 1992 (Table 2). Settlement of xanthid megalopae was significantly greater than expected during southward wind events in 1991, but there was no difference between observed and expected frequencies during positive anomalies in either year.
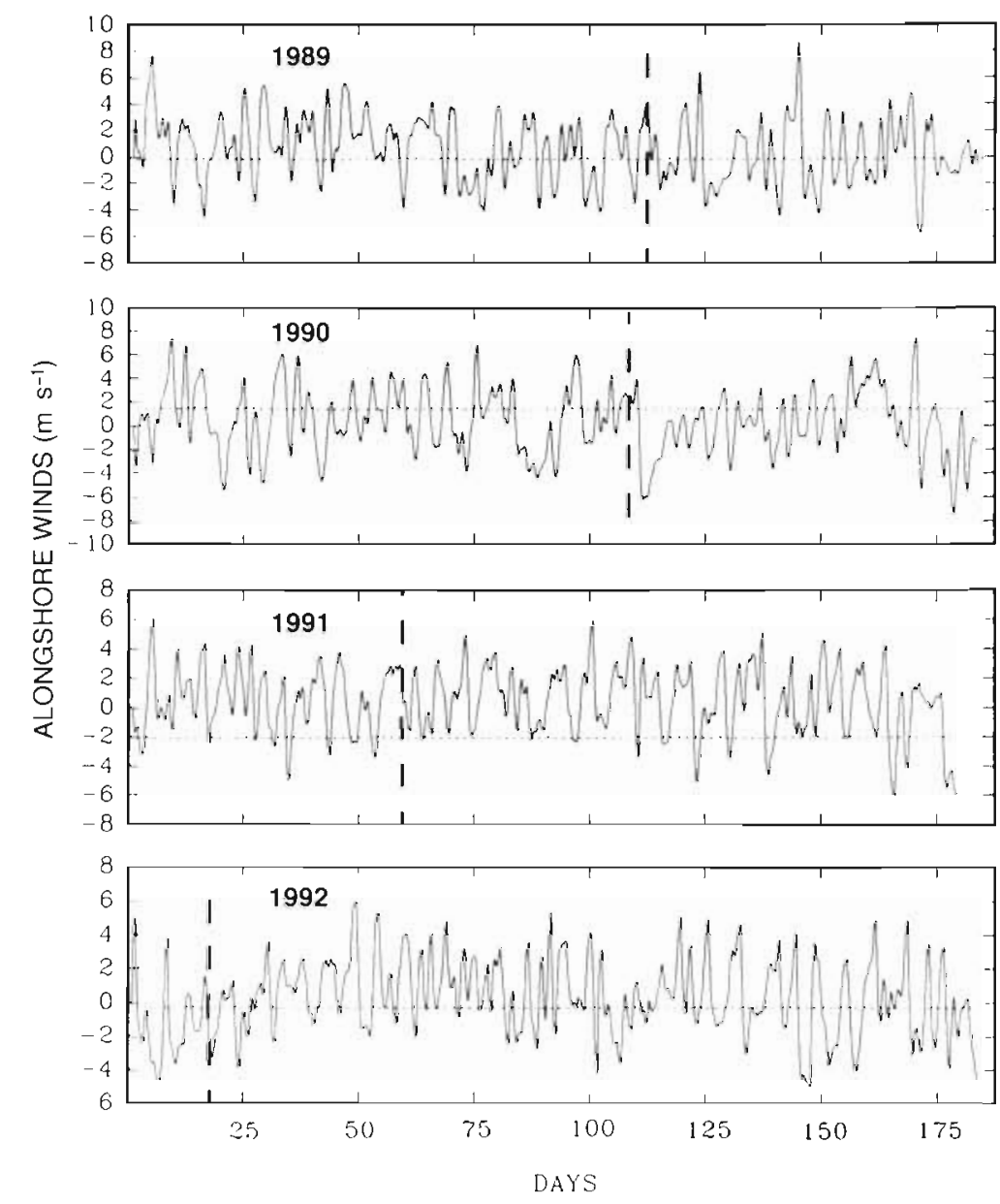

MAY

J 11

Alici

SFI'

ol' 1 NOV

Fig. 4. Filtered time series (see 'Materials and methods') of alongshore winds $\left(\mathrm{m} \mathrm{s}^{-1}\right)$ for each year Values $>0$ are northward blowing; values $<0$ are southward blowing. Dotted vertical lines indicate initiation of biological sampling each year

\section{DISCUSSION}

\section{Seasonal and annual variation in settlement}

Results from the present study show different seasonal patterns in the respective settlement of fiddler crabs, mud crabs, and blue crabs in Delaware Bay. This is probably due to the different life-history patterns of the taxa. Both species of Uca and all local species of xanthids begin spawning in early summer and spawn into August. In contrast, maximum spawning of Callinectes sapidus occurs in late July and continues into September (Dittel \& Epifanio 1982). Therefore, settlement in C. sapidus was expected to begin later and extend farther into autumn. The somewhat broader settlement season for xanthids and for Uca spp. may have reflected the multi-species composition of these 2 taxa, e.g. the 4 species included in the xanthid category may have had different peaks in spawning activity (Dittel \& Epifanio 1982).

Callinectes sapidus showed the smallest interannual variation in both the number of settlement events and the total number of megalopae settling. This is surprising because $C$. sapidus has the least conservative life history (i.e. long duration of larval development and open-sea dispersal) among the 3 taxa in the study, and present theory predicts that this should exacerbate interannual variation in larval settlement (e.g. Roughgarden et al. 1988, Epifanio 1994). We were only able to compare 2 years of settlement for Uca spp. and for xanthids. Nevertheless, interannual variation in both number of megalopae and number of events was substantial. More than 3 times as many Uca spp. settled in 1991 as in 1992. Both the number of settlement events and the number of megalopae 


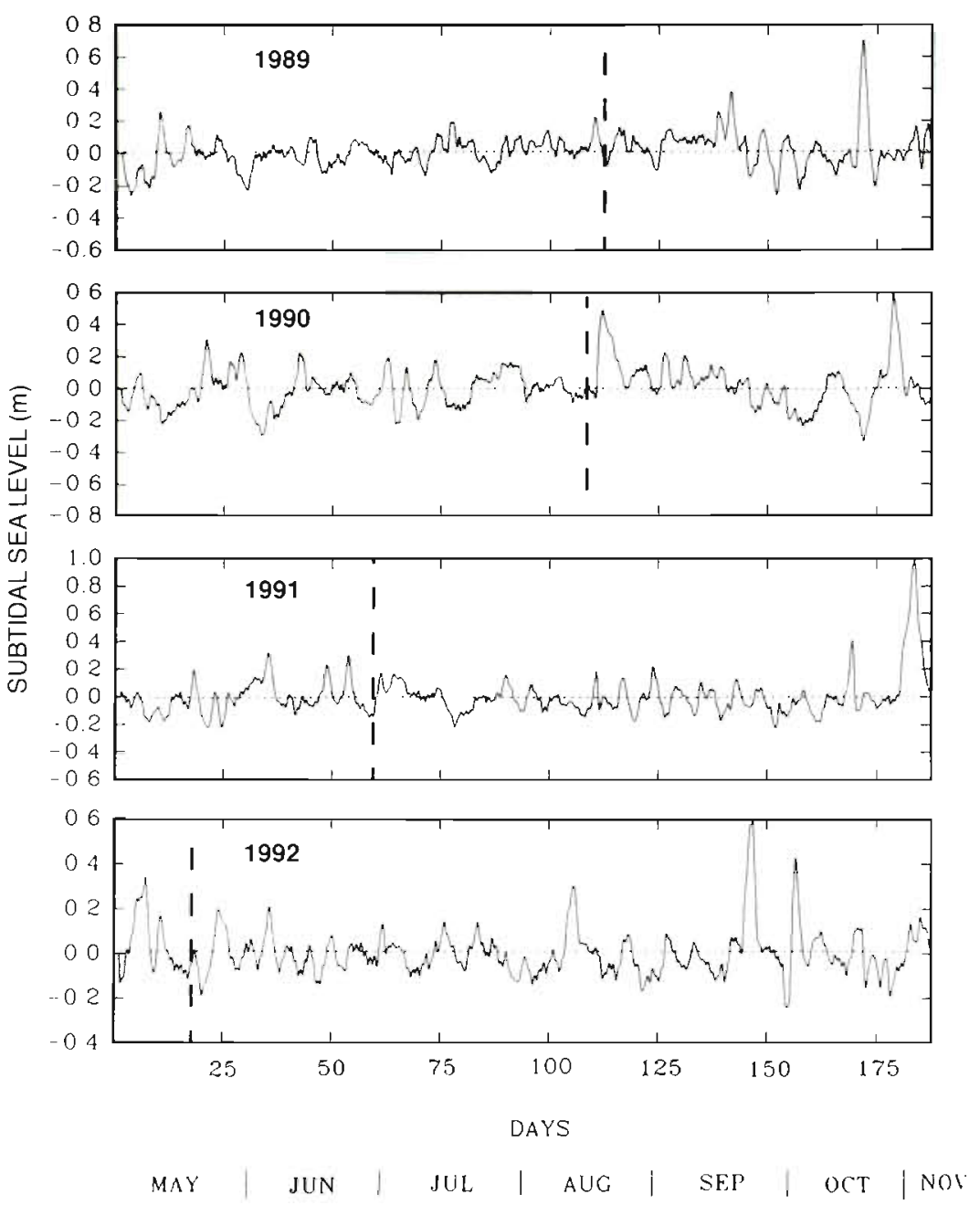

Fig. 5. Filtered time series (see 'Materials and methods') of subtidal sea level (m) for each year. Mean subtidal sea level for each study period was assigned a value of zero. Dotted vertical lines indicate initiation of biological sampling each year

reached a nadir in 1992 for xanthids: more than 20 times as many individuals were collected in 1991. The xanthid result is particularly surprising because of the conservative-life-history species in this taxon, i. e. short larval duration and estuarine retention. Any grand conclusion is risky because of the small number of years in the study and because the record for fiddler crabs and xanthid crabs contains data for more than 1 species. Nevertheless, the results show the potential for large interannual variations in settlement, even for species with conservative life histories.

\section{Lunar phase and spring/neap cycle}

In the present study, no relationship was found between megalopal settiement and lunar phase. This is in contrast to the results of van Montfrans et al. (1990), who reported maximum settlement of Callinectes sapidus in Chesapeake Bay at the time of and just after full moon. Related work by Boylan \& Wenner (1992) found the greatest abundances of $C$. sapidus megalopae in Charleston Harbor, South Carolina occurred at times of the fouth lunar quarter (i.e. waning moon). A lunar rhythm in settlement could be related to lunar rhythms in behavior; for example, megalopae could migrate up in the water column during flood tides associated with a particular lunar phase. However, it seems unlikely that the behavior would differ among estuaries, e.g. no behavior in Delaware Bay, full-moon behavior in Chesapeake Bay, and waning-moon behavior in Charleston Harbor. Alternatively, the reported association with lunar phase could be an auto-correlation related to the spring/neap cycle. For example, flood tides at full and new moon periods (i.e. spring tides) have a greater volume than flood tides on the lunar quarters (i.e. neap tides). A patch of megalopae occurring near the estuarine mouth during spring tides would have a greater chance of being transported into the estuary. However, there seems to be little consistency among estuaries. Maximum settlement in Charleston Harbor occurred during neap tides, while maximum settlement in one study in the Chesapeake Bay (van Montfrans et al. 1990) occurred during spring tides. In a more recent investigation in Chesapeake Bay, Olmi (1995) reported a significant correlation between tidal range and abundance of blue crab megalopae in the water colum in 1987 and 1988, but not in 1989. In Delaware Bay, we found no relationship between settlement of $C$. sapidus and the spring/neap cycle.

In the present study, settlement of xanthid megalopae showed no tidal pattern in either year. This result agrees with van Montfrans et al. (1990), who showed no correlation between tidal range and xanthid settlement in the Chesapeake. Spawning in Uca minax and $U$. pugnax is clearly associated with nocturnal spring tides (Wheeler 1978), however there is no consistent indication of spring/neap rhythm in settlement (Christy 1982, Epifanio et al. 1988). Our own results are unclear, as we found a significant difference in 
observed and expected settlement during spring tides in only 1 year.

\section{Winds and sea level}

Results of our investigation show a strong association between the settlement of Callinectes sapidus and both southward wind events and the consequent increase in coastal sea level. Observed settlement was significantly greater than expected settlement during southward wind events in all 4 years and was significantly greater than expected settlement during positive SSL anomalies in 3 of the 4 years of the study. The association of $C$. sapidus settlement with both southward winds and positive SSL anomalies concurs with our present understanding of near-shore physical processes in the MAB. For example, Wong \& Garvine (1984) showed how southward wind forcing results in subtidal transport of water from the continental shelf into Delaware bay. This transport of water begins about $12 \mathrm{~h}$ after the onset of a wind event, and the wind events usually last 2 to $3 \mathrm{~d}$. If this process is important in transporting megalopae from the adjacent continental shelf into the estuary, it makes sense that settlement should be associated with both the wind event and the consequent increase in SSL.

Earlier investigations with Callinectes sapidus have shown similar results. Little \& Epifanio (1991) and Goodrich et al. (1989) analyzed their results as binomial distributions and found that the observed frequencies of settlement during positive SSL anomalies were significantly greater than expected in Delaware Bay and Chesapeake Bay respectively. Hudon \& Fradette (1993) reported that alongshore winds were important in the onshore transport of American lobster Homarus americanus, the rock crab Cancer irroratus, and the toad crab Hyas spp. in the Gulf of St. Lawrence. In more recent work in the Chesapeake Bay, Olmi (1995) used correlative techniques to analyze data from passive collectors (similar to those used in the present study) and found that settlement of blue crab megalopae was associated with westward wind stress. This is difficult to explain because the predominant winds in the Chesapeake region blow north/south with a relatively weak westward component. Additionally, Ekman flow associated with westward blowing winds would be to the north, which is alongshore rather than onshore.

In Delaware Bay, we found a possible association between southward alongshore winds (i.e. southward winds) and the settlement of xanthid megalopae in only 1 year, but we found no relationship between settlement of $U_{c a}$ spp. or xanthids and positive anomalies in SSL. An inspection of the relevant data sets showed that xanthid larvae tended to be associated with very weak southward winds ( $\left.<1 \mathrm{~m} \mathrm{~s}^{-1}\right)$ that did not result in positive anomalies. It is not clear whether data from a greater number of years would support the apparent association with weak southward winds, but it is clear that xanthids are not transported to settlement sites by southward winds because it is the rise in coastal sea level, not the southward wind event, that actually causes the subtidal flow from the continental shelf into the estuary.

In summary, our findings provide additional support for the present conceptual model concerning advective transport of crab larvae in the Middle Atlantic Bight (Epifanio et al. 1988, Epifanio 1994). Of the 3 taxa studied, only Callinectes sapidus relies on wind-driven processes for transport to settlement sites. Transport of C. sapidus megalopae back into the estuary requires the coincident occurrence of a southward, alongshore wind event and a nearby patch of megalopae. The stochastic nature of this co-occurrence explains the observed temporal variations in settlement of $C$. sapidus in the estuary.

Acknowledgements. We thank Victoria Connaughton, James Welch, Janet Duffy, Sarah Schoedinger, Richard Terrel, and a host of summer interns for assisting in collection of megalopae. The Pennsylvania Navy provided boat wakes that made sampling a true adventure, while Richard Garvine, Romuald Lipcius, and Peter Rowe provided critical comments on an earlier draft of the manuscript. The study was supported by funds provided from the Sea Grant College Program at the University of Delaware

\section{LITERATURE CITED}

Boylan JM, Wenner EL (1992) Settlement of brachyuran megalopae in a South Carolina, USA, estuary. Mar Ecol Prog Ser 97:237-246

Brookins KG, Epifanio CE (1985) Abundance of brachyuran larvae in a small coastal inlet over six consecutive tidal cycles. Estuaries 8:60-67

Christy JH (1982) Adaptive significance of semilunar cycles of larval release in fiddler crabs (Genus $U_{c a}$ ): test of an hypothesis. Biol Bull 163:251-263

Cronin TW (1982) Estuarine retention of larvae of the crab Rhithropanopeus harrisii. Estuar coast Shelf Sci 15: $207-220$

Cronin TW, Forward RB Jr (1979) Tidal vertical migration: an endogenous rhythm in estuarine crab larvae. Science 205 : 1020-1022

Dittel AI, Epifanio CE (1982) Seasonal abundance and vertical distribution of crab larvae in Delaware Bay. Estuaries 5:197-202

Dittel AI, Epifanio CE, Lizano O (1991) Flux of crab larvae in a mangrove creek in the Gulf of Nicoya, Costa Rica. Estuar coast Shelf Sci 32:129-140

Epifanio CE (1995) Transport of blue crab (Callinectes sapidus) larvae in the Middle Atlantic Bight. Bull mar Sci (in press)

Epifanio CE, Little KT, Rowe PM (1988) Dispersal and recruitment of fiddler crab larvae in the Delaware River estuary. 
Mar Ecol Prog Ser 43:181-188

Epifanio CE, Masse AK, Garvine RW (1989) Transport of blue crab larvae by surface currents off Delaware Bay, USA. Mar Ecol Prog Ser 54:35-41

Epifanio CE, Valenti CC, Pembroke AE (1984) Dispersal and recruitment of blue crab larvae in Delaware Bay, USA. Estuar coast Shelf Sci 18:1-12

Goodrich DM, van Montfrans J, Orth RJ (1989) Blue crab megalopal influx to Chesapeake Bay: evidence for a winddriven mechanism. Estuar coast Shelf Sci 29:247-260

Hudon C. Fradette P (1993) Wind-induced advection of larval decapods into Baie de Plaisance (Iles de la Madeleine, Quebec). Can J Fish Aquat Sci 50:1422-1434

Johnson DF (1985) The distribution of brachyuran crustacean megalopae in the waters of the York River, lower Chesapeake Bay and adjacerit shelf: implications for recruitment. Estuar coast Shelf Sci 20:693-705

Little KT, Epifanio CE (1991) Mechanism for the re-invasion of an estuary by two species of brachyuran megalopae. Mar Ecol Prog Ser 68:235-242

McConnaugha JR (1988) Export and reinvasion of larvae as regulators of estuarine decapod populations. Am Fish Soc Symp 3:90-103

McConnaugha JR, Johnson DF, Provenzano AJ, Maris $R C$ (1983) Seasonal distribution of larvae of Callinectes sapidus (Crustacea: Decapoda) in the waters adjacent to Chesapeake Bay. J Crust Biol 3:582-591

Metcalf KS, Lipcius RN (1992) Relationship of habitat and spatial scale with physiological state and settlement of blue crab postlarvae in Chesapeake Bay. Mar Ecol Prog Ser 2:143-150

van Montfrans J, Peery CA, Orth RJ (1990) Daily, monthly and

This article was submitted to the editor annual settlement patterns by Callinectes sapidus and Neopanope sayi megalopae on artificial collectors deployed in the York River, VA: 1985-1988. Bull mar Sci 46:214-229

Noble M, Butman B (1979) Low-frequency wind-induced sea level oscillations along the East Coast of North America. J geophys Res $54(c 6): 3227-3236$

Olmi EJ (1995) Ingress of blue crab megalopae in the York River, Virginia, 1987-1989. Bull mar Sci (in press)

Provenzano AJ Jr, McConaugha JR, Philips KB, Johnson DF, Clark J (1983) Vertical distribution of first stage larvae of the blue crab Callinectes sapidus, at the Mouth of Chesapeake Bay. Estuar coast Shelf Sci 16:489-499

Roughgarden JS, Gaines S, Possingham H (1988) Recruitment dynamics in complex life cycles. Science 241:1460-1466

Rowe PM, Epifanio CE (1994) Tidal stream transport of weakfish in Delaware Bay, USA. Mar Ecol Prog Ser 110: $105-114$

Sulkin SD, Van Heukelem W, Kelly P (1983) Behavioral basis of depth regulation in the hatching and post-larval states of the mud crab Eurypanopeus depressus Hay and Shore. Mar Ecol Prog Ser 11:157-164

Wheeler D (1978) Semilunar hatching periodicity in the mud crab Uca pugnax (Smith). Estuaries 1:268-269

Wheeler DE, Epifanio CE (1978) Behavioral response to hydrostatic pressure in larvae of two species of xanthid crabs. Mar Biol 46:167-174

Wong KC, Garvine RW (1984) Observations of wind-induced, subtidal variability in the Delaware estuary. J geophys Res 89:10589-10597

Zar JH (1984) Biostatistical analysis, 2nd edn. Prentice Hall, Inc, Englewood Cliffs, NJ

Manuscript first received: September 20, 1994

Revised version accepted: January 31, 1995 